\title{
THE HYDRO-CHEMICAL CHARACTERISTICS OF A KARST FAULTED BASIN: CASE STUDY OF THE BAIYI BASIN, KUNMING, CHINA
}

\author{
Hong Liv \\ Dan Cuicui \\ Yang Liu \\ Mengmeng Wang \\ International Joint Research Center for Karstology, Yunnan University, No. 5 Xueyun Road, WuHua District, \\ Kunming, Yunnan, 650223, China,hongliu@ynu.edu.cn
}

\begin{abstract}
A fault-controlled karst basin is a special type of karst landform. It is defined as a basin-like topography surrounded by mountains, which is fully or partly karstified. Fault-controlled karst basins play a great role on urbanization and economic development of Yunnan Province which is located in a mountainous region. Baiyi Basin is a sub-basin of the Kunming faulted Basin with typical hydrogeological characteristics for a faultcontrolled karst basin. It is also one of the most important drinking water source protection zones of Kunming City. In order to better understand the hydrogeological nature of this fault-controlled karst basin and to better protect the valuable groundwater resources, a pilot study focusing on the hydrochemical characteristics of faultcontrolled karst basin springs was carried out in Baiyi Basin. A total of 10 springs in the basin are selected in this study. Water Temperature, Electric Conductivity (EC), and $\mathrm{pH}$ value were measured in situ. Water samples from these 10 springs were analyzed for $\mathrm{Ca}^{2+}, \mathrm{HCO}_{3}^{-}, \mathrm{F}^{-}, \mathrm{Cl}^{-}$, $\mathrm{NO}_{3}^{-}, \mathrm{Br}$, DOC, DIC contents and stable isotopic ratios $\left(\delta^{18} \mathrm{O}\right.$ and $\left.\delta^{2} \mathrm{H}\right)$. Results show that (1) the hydrochemical characteristics of fault-controlled karst basin are more complex than for a normal basin owing to the intense tectonic activities. Within the Baiyi fault-controlled karst basin, there are not only epikarst springs, shallow karst springs, and confined karst springs, but also nonkarst springs. Even deep groundwater may be involved in the water cycle. (2) Water isotopic data reveal that Qinglongtan (QLT) Springs (QLT1 to QLT4) and a Heilongtan Spring (HeiLT1) share a common recharge water source. (3) Among 9 of 10 studied springs, nitrate concentrations slightly exceed of the drinking water standard $(10 \mathrm{mg} / \mathrm{l})$.
\end{abstract}

\section{Introduction}

A fault-controlled karst basin is a special type of karst landform. It is defined as a basin-like topography that surrounded by mountains, which is fully or partly karstified. Due to the unique geographical location, there are more than 1440 faulted basins and most of them are fault-controlled karst basin in Yunnan Province, China. They play a great role in economic development and urbanization in Yunnan Province. Nearly all major cities are located in faulted basins.

Every fault-controlled karst basin has its own evolutionary history, lithological units, and hydrogeological characteristics. Hydrologically, the karst basins can be divided into two types. One type formed its own "central radiating flow system" on the basin level. Karst water from mountainous recharge areas emerges at the edge of the basin where it meets Quaternary sediments and forms a series of karst springs in the basin. Another type is designated as a "through water system", where water influx from karstic mountains, mostly flows through underground conduits to other water systems instead of flowing to the bottom of the basin (Wang et al., 2003). In general, fault-controlled karst basins are located in the watershed areas of the tributaries of Yangtze River, Pearl River, or Honghe River in Yunnan Province. The water in the basin is an important water source for the municipal water supply, agriculture irrigation, and industry. With the rapid urbanization and economic development of Yunnan Province, especially under global climate change, the water shortage issue has limited economic development and the urbanization process.

Baiyi Basin is a sub-basin of the Kunming faulted Basin. There are many big springs developed along the edge of the basin, and the water flows into a catchment, named Lake Songhuaba, the main drinking water source of Kunming City. The basin has been designated as the drinking water source protection zone of Kunming City in 1981. A comprehensive investigation was carried out in the entire water source protection area in 1988 
(Kunming EPA report, 1988). However, very little research work focused on the faulted basin, especially the overall hydrogeological processes in faulted karst basin, has been conducted.

In order to better understand the hydrogeological processes of the fault-controlled karst basin and to better protect the important groundwater resources, a pilot study focusing on the hydrochemical characteristics of fault-controlled karst springs has been carried out in Baiyi Basin.

\section{Study Area and Methods}

Baiyi Basin is a typical fault-controlled karst basin, about $40 \mathrm{~km}$ north of downtown Kunming, the capital city of Yunnan Province. It extends along the main south to north tectonic strike (Figure 1). The host rocks of the karst aquifers are Paleozoic carbonates, which are widely distributed in the north, south and southwest of the basin. Lithologically, the Permian and Carboniferous carbonate formations are limestones, and the Silurian and Devonian rocks are dolomitic limestone. The groundwater catchment of the basin is consistent with the surface watershed, except for the north, where middle Devonian dolomitic limestone $\left(\mathrm{D}_{2} \mathrm{~h}^{1-1}\right)$ exists as the boundary.

This area belongs to the low latitude plateau monsoon climate. The annual temperature is $13.8^{\circ} \mathrm{C}$, and precipitation is $1030.5 \mathrm{~mm}$. It could be divided into two seasons, May to October is the wet season with $89 \%$ of total rainfall. November to April belongs to the dry season, with $11 \%$ of annual precipitation.

In north, south, and southwest mountainous area of the basin, karst features such as depressions, dolines, and shafts are extensively developed. The northern part belongs to the Liangwangshan karst highland, and "temporary" sinkholes are well developed because of soil collapse. All of those landforms indicate that precipitation could rapidly infiltrate into the underground aquifer. As a consequence, local residents can only rely on rainwater harvest systems and intermittent epikarst springs to resolve drinking water problems. No surface water flows into the basin, therefore all the water must come from rainfall.

Along the edge of Baiyi Basin, there are many springs formed. Among them, the Qinglongtan groups of springs
(QLT), Heilongtan Spring (HeiLT), Huanglongtan Spring (HLT) could be the most noted for their significant discharges.

The QLT group of springs, with more than 4 springs concentrated in a small area located at the northern edge of the basin, contribute the source water of Panlongjiang River, which has been named as the mother river of Dianchi Lake, the largest lake (water surface) in Yunnan. During summer, almost one third of discharge of the Panlongjiang River comes from the QLT springs. Near the main outlet of the QLT Springs, Lengshuidong Cave extends from south to north with a length of 300 meters and ends in a sump in the northern end. It is dry in the dry season and flooded in wet season with a discharge over $2 \mathrm{~m}^{3} / \mathrm{s}$. The elevations of the QLT springs are relatively higher than the cave but the springs have water permanently except for extreme droughts.

HeiLT is located on the eastern edge of the basin, with a discharge about $0.4 \mathrm{~m}^{3} / \mathrm{s}$. Personal communications with villagers indicate that the spring water becomes muddy

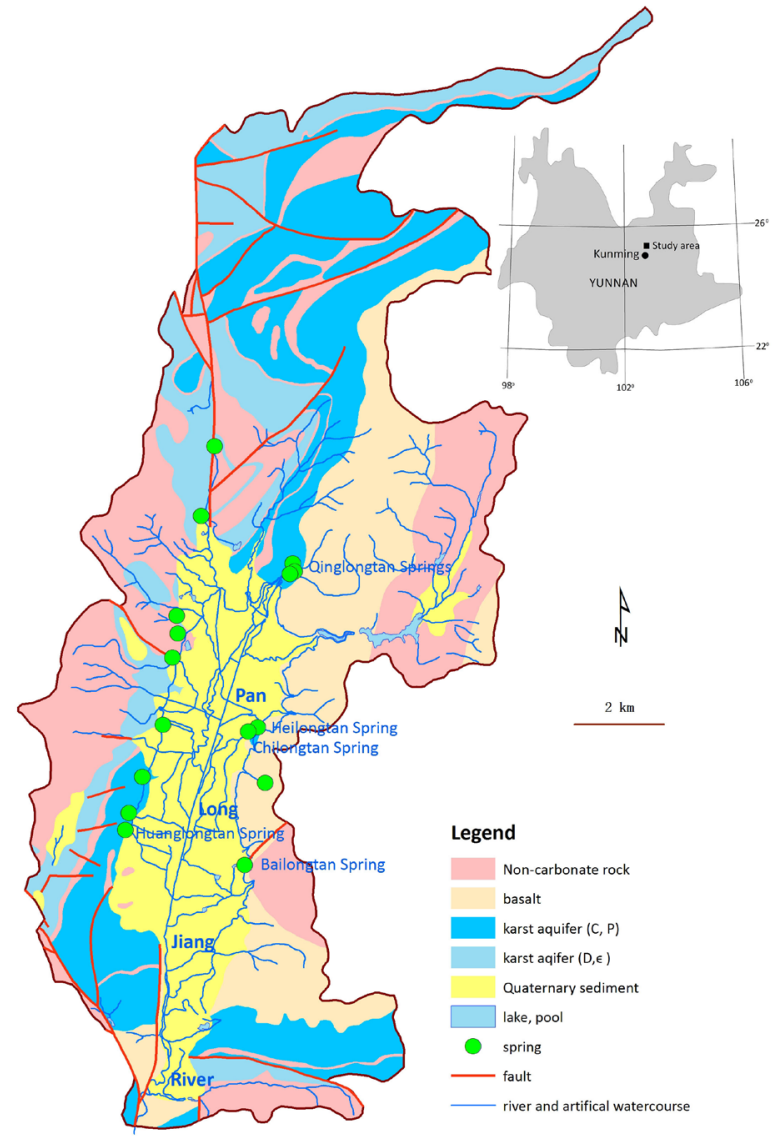

Figure 1. Hydrogeological map of the Baiyi Basin. 
with high turbidity for a few days after the first heavy rain at the start of wet season. Two meters away from the main outlet of the spring, there is a small spring with a flow rate less than $0.5 \mathrm{l} / \mathrm{s}$. Chilongtan Spring (CHLT), 30 meters west of HeiLT, is a small spring, and the discharge is approximately 8 to $10 \mathrm{l} / \mathrm{s}$. The temperature of CHLT is usually 4 to $5^{\circ} \mathrm{C}$, higher than that of HeiLT.

HLT appears at the western edge of the basin, and the ratio of discharges in wet season and in dry season is greater than 5 . There are several small springs near HLT and the largest one has a discharge of 1 1/s.

Bailongtan Spring (BLT) is a relative small spring with a discharge about 5 to $7 \mathrm{l} / \mathrm{s}$. The water infiltrates from nearby hills.

In addition to the springs described above, there are a few more springs but most of them have been used as the local drinking water sources or hardly to identify from the wet land around them. All these springs have been sampled during this study.

Five springs were sampled as part of a Chinese-Slovene project in June 2006 and several physical and chemical parameters were analyzed. Water temperature (T), $\mathrm{pH}$, and electrical conductivity (EC) were measured in situ with WTW MultiLine P4. Total hardness ( $\mathrm{Ca}+\mathrm{Mg})$ and calcium content $(\mathrm{Ca})$ were determined using the standard titrimetric method (Greenberg et al., 1992). In November 2007, 3 springs were sampled for oxygen isotope analysis in the isotope lab, Institute of Geology and Geophysics, Chinese Academy of Sciences.

Water samples from 10 springs were collected in December 2016 to analyze concentrations of $\mathrm{Ca}^{2+}, \mathrm{HCO}_{3}^{-}, \mathrm{F}^{-}, \mathrm{Cl}^{-}$, $\mathrm{NO}_{3}^{-}, \mathrm{Br}^{-}$, DOC, DIC and stable isotopes $\left(\delta^{18} \mathrm{O}\right.$ and $\left.\delta^{2} \mathrm{H}\right)$. $\mathrm{T}, \mathrm{EC}$, and $\mathrm{pH}$ parameters were measured in situ by using a Hach HQ40d multi-parameter water quality mater. $\mathrm{Ca}^{2+}$ and $\mathrm{HCO}_{3}^{-}$were determined by using MColortest calcium test and alkalinity test box respectively in the field. $\mathrm{F}^{-}, \mathrm{Cl}^{-}, \mathrm{NO}_{3}^{-}, \mathrm{Br}^{-}$were analyzed by DIONEX ICS1100 Ion Chromatography System. DOC, DIC were determined by using the Analytik Jena Multi N/C 3100 instrument and stable isotope $\left({ }^{18} \mathrm{O}\right.$ and $\left.{ }^{2} \mathrm{H}\right)$ were analyzed using a Laser Absorption Spectroscopy (LAS) performed on the TIWA-45EP analyzer (Los Gatos Research) in Karst Lab of International Joint Research Center for Karstology, Yunnan University. Isotope measurements were performed against three laboratory standards covering ranges from $-51 \%$ to $-123.6 \%$ (VSMOW) for $\delta^{2} \mathrm{H}$ and from $-7.69 \%$ to $-16.14 \%$ (VSMOW) for $\delta^{18} \mathrm{O}$ with precisions better than $0.1 \%$ for oxygen isotope and better than $0.5 \%$ o for hydrogen isotope.

\section{Results and Discussion}

Measured temperature, conductivity (EC) and the ratio of calcium to magnesium $(\mathrm{Ca} / \mathrm{Mg})$ of the 5 springs in June 2006 are illustrated in Figure 2a.

Temperature varies from $15.1^{\circ} \mathrm{C}$ to $20.5^{\circ} \mathrm{C}$. EC varies from 247 to $383 \mu \mathrm{S} / \mathrm{cm}$ and $\mathrm{Ca} / \mathrm{Mg}$ varies from 1.9 to 3.4. With respect to temperature, $\mathrm{EC}$ and $\mathrm{Ca} / \mathrm{Mg}$, they were $15.1{ }^{\circ} \mathrm{C}, 20.5^{\circ} \mathrm{C}, 15.9^{\circ} \mathrm{C}, 15.1{ }^{\circ} \mathrm{C}$ and $17.1^{\circ} \mathrm{C} ; 247,284$, 263, 251, and $383 \mu \mathrm{S} / \mathrm{cm}, 3.3,2.4,3.4,2.2$ and 1.9 for QLT1, CHLT, HeiLT1, HLT2, and HLT1, respectively (Figure 2a). The EC value of springs was much lower than the value of karst springs in other places. The EC of Qinglongdong Spring (28 km northeast of Kunming) oscillated between 404 and $483 \mu \mathrm{S} / \mathrm{cm}$ during the same time period for instance. These results indicate that water from the springs might be contributed from different sources.

Ten springs were sampled and measured in November 2016 (Figure 2b). The temperature of spring water ranged from $13.9^{\circ} \mathrm{C}$ to $18.4^{\circ} \mathrm{C}$, clearly 1 to $2^{\circ} \mathrm{C}$ lower than that of June 2006 because of the cooler air temperature. On the contrary, the EC of spring samples somewhat increased, except for the EC of CHLT remained the same. The concentrations of $\mathrm{HCO}_{3}{ }^{-}$and $\mathrm{Ca}^{2+}$ were unanimous for most springs falling into the range of $2.8 \mathrm{meq} / 1$ to $3.1 \mathrm{meq} / 1$ for $\mathrm{HCO}_{3}{ }^{-}$and $57 \mathrm{mg} / 1$ to $68 \mathrm{mg} / \mathrm{l}$ for $\mathrm{Ca}^{2+}$ except for BLT and HLT1, which were $0.7 \mathrm{meq} / 1$ and $17 \mathrm{mg} / 1$ for BLT and $4.3 \mathrm{meq} / 1$ and $102 \mathrm{mg} / 1$ for HLT1 respectively. BLT is not a karst spring. The DOC and DIC values among springs fell in the range of $2.94 \mathrm{mg} / 1$ to $4.53 \mathrm{mg} / 1$ and $28.79 \mathrm{mg} / 1$ to $33.27 \mathrm{mg} / 1$ except for BLT and HLT1, which were $1.05 \mathrm{mg} / \mathrm{l}$ and $0.79 \mathrm{mg} / \mathrm{l}$ for BLT and $5.5 \mathrm{mg} / 1$ and $49.36 \mathrm{mg} / 1$ for HLT1 respectively.

The concentration of $\mathrm{F}^{-}$was $0.21 \mathrm{mg} / \mathrm{l}$ in HLT1 and undetectable in the other 9 springs. The concentration of $\mathrm{Cl}^{-}$was between 0 to $2.43 \mathrm{mg} / 1$. $\mathrm{Cl}^{-}$concentrations for 8 of 10 springs were below $0.84 \mathrm{mg} / 1 . \mathrm{Cl}^{-}$concentrations of HLT1 and HLT2 were $2.43 \mathrm{mg} / \mathrm{l}$ and $1.93 \mathrm{mg} / \mathrm{l}$ respectively. 

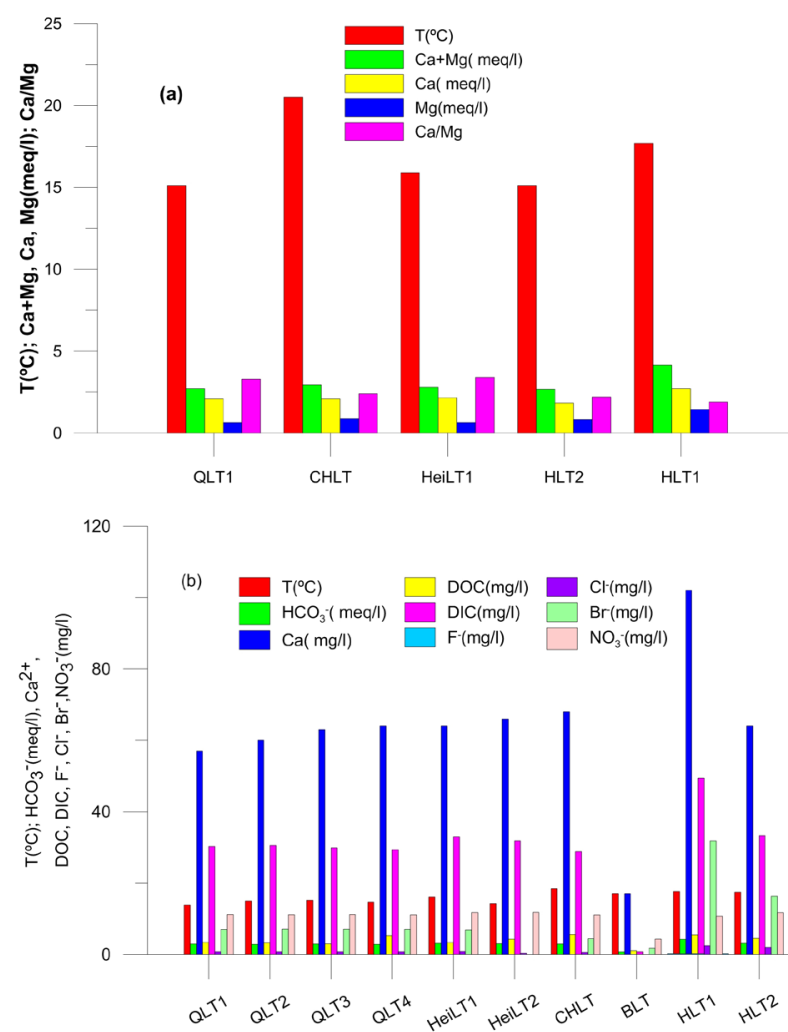

Figure 2. Hydrochemical parameters of samples: a, from QLT1, CHLT, HeiLT1, HLT2 and HLT1 springs in- June 2006 (upper panel); $b$, from QLT1, QLT2, QLT3, QLT4, HeiLT1, HeiLT2, CHLT, BLT, HLT1 and HLT2 springs in November 2016 (lower panel).

$\mathrm{Br}^{-}$concentrations varied widely, from undetectable in HeiLT2, to $31.81 \mathrm{mg} / \mathrm{l}$ in HLT1. Br is mainly come from specific host rocks. In other words, the difference of $\mathrm{Br}^{-}$concentrations enabled an initial distinction of groundwater flow path or host rock. For QLT1 to QLT4 and HeiLT1, the value of $\mathrm{Br}^{-}$concentration was coincident in a range of $6.84 \mathrm{mg} / \mathrm{l}$ to $7.04 \mathrm{mg} / \mathrm{l}$, but $4.45 \mathrm{mg} / \mathrm{l}$ in CHLT and $1.73 \mathrm{mg} / \mathrm{l}$ in BLT. The highest value was found in HLT1, $31.81 \mathrm{mg} / 1$ and the second highest in HLT2, $16.32 \mathrm{mg} / \mathrm{l}$.

Nitrate concentration was $4.33 \mathrm{mg} \mathrm{NO} \mathrm{NO}^{-/ 1}$ for BLT. Nitrate concentrations $(10.76 \mathrm{mg} / \mathrm{l}$ to $11.77 \mathrm{mg} / \mathrm{l})$ for the other 9 springs were slightly higher than the drinking standard, $10 \mathrm{mg} / \mathrm{l}$. The nitrate concentration exhibits an increasing trend in the last 10 years, from $4 \mathrm{mg} / \mathrm{l}$ (Šebela et al, 2006) to about $10 \mathrm{mg} / 1$ in QLT1.

Results of three ${ }^{18} \mathrm{O}$ isotopic water samples from November 2007 showed that the QLT1 and HeiLT1 shared the same $\delta^{18} \mathrm{O}$ value of $-12.28 \%$, which is slightly heavier than that of CHLT, $-12.60 \%$. This suggested that QLT1 and HeiLT1 might have same water source.

In December 2016, water samples for isotopic analysis were taken from 10 springs. Results are shown in Figure 3. The distinct lighter water stable isotopic values of BLT $\left(\delta^{2} \mathrm{H}-93.31 \%\right.$ and $\delta^{18} \mathrm{O}-12.68 \%$ ) indicates that it has a different water source from other springs. CHLT $\left(-12.70 \%\right.$ for $\delta^{18} \mathrm{O}$ and $-90.95 \%$ for $\left.\delta^{2} \mathrm{H}\right)$ may also have its own source water. Isotopic values of QLT1 $\left(\delta^{2} \mathrm{H}\right.$ $-87.67 \%$, $\delta^{18} \mathrm{O}-12.53 \%$ ), QLT2 $\left(\delta^{2} \mathrm{H}-87.57 \%\right.$, $\delta^{18} \mathrm{O}$ $-12.48 \%)$, QLT3 $\left(\delta^{2} \mathrm{H}-88.26 \%\right.$, $\delta^{18} \mathrm{O}-12.47 \%$ ), QLT4 $\left(\delta^{2} \mathrm{H}-88.16 \%, \delta^{18} \mathrm{O}-12.41 \%\right)$, HeiLT1 $\left(\delta^{2} \mathrm{H}-87.84 \%\right.$, $\delta^{18} \mathrm{O}-12.44 \%$ ) cluster together and indicate that they might have a common recharge water source. HeiLT2 $\left(\delta^{2} \mathrm{H}-86.84 \%\right.$, $\left.\delta^{18} \mathrm{O}-11.72 \%\right)$, HLT1 $\left(\delta^{2} \mathrm{H}-85.21 \%\right.$, $\left.\delta^{18} \mathrm{O}-11.89 \%\right)$ and HLT2 $\left(\delta^{2} \mathrm{H}-84.93 \% 0\right.$ and $\delta^{18} \mathrm{O}$ $-11.48 \%$ o) have heavier isotopic values and scattered away from each other.

Taking all hydrochemical characteristics of the water samples and field investigation into consideration, spring water in Baiyi Basin could be divided into five groups (Table 1).

Group 1, BLT. The spring has distinctive stable isotope values, limited discharge, and electrical conductivity and bicarbonate concentration are very low. It is formed by rainwater percolating through non-carbonate rock or sediments. This is a non-karst water spring.

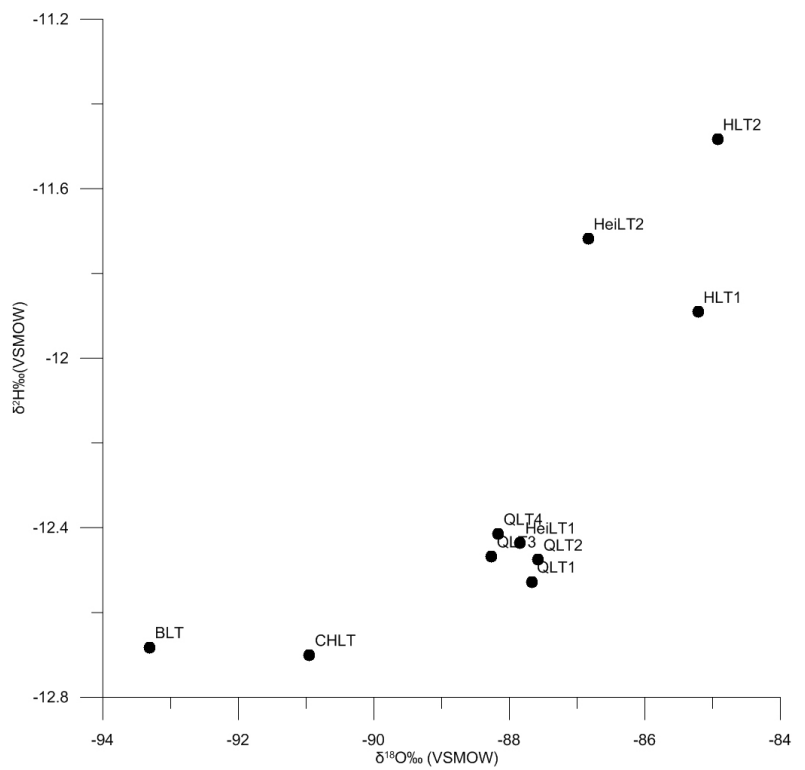

Figure 3. Isotopic analysis results of samples from December 2016. 


\begin{tabular}{|l|l|l|}
\hline Group\# & Springs & Hydrochemical characteristics \\
\hline 1 & BLT & $\begin{array}{l}\text { distinctive stable isotope values; very Low } \\
\text { EC and bicarbonate concentrations. }\end{array}$ \\
\hline 2 & CHLT & $\begin{array}{l}\text { distinctive stable isotope values; higher } \\
\text { water temperature and constant discharge. }\end{array}$ \\
\hline 3 & $\begin{array}{l}\text { QLT1, } \\
\text { QLT2, } \\
\text { QLT3, } \\
\text { QLT4, } \\
\text { HeiLT1 }\end{array}$ & $\begin{array}{l}\text { similar hydrochemical characteristics and } \\
\text { stable isotope values; relatively stable } \\
\text { discharge; weak confined water }\end{array}$ \\
\hline 4 & $\begin{array}{l}\text { HeiLT2, } \\
\text { HLT1 }\end{array}$ & $\begin{array}{l}\text { water temperature sensitive to air } \\
\text { temperature; limited discharge (<51/s); } \\
\text { fracture-controlled infiltration. }\end{array}$ \\
\hline 5 & HLT2 & $\begin{array}{l}\text { spring discharge and hydrochemical } \\
\text { parameters oscillate greatly during dry and } \\
\text { wet seasons; downstream has karst window } \\
\text { in contact with open air and subterranean } \\
\text { river }\end{array}$ \\
\hline
\end{tabular}

Table 1. Five groups of springs and their major hydrochemical characteristics in the Baiyi Basin.

Group 2, CHLT. The spring has distinctive stable isotope values. The water temperature is 2 to $4^{\circ} \mathrm{C}$ higher than surrounding springs. Discharge and EC are relatively constant. It might be the mixture of deep groundwater and karst water.

Group 3, QLT1, QLT2, QLT3, QLT4, HeiLT1. These 5 springs have similar hydrochemical characteristics and stable isotope values. Groundwater flows from mountainous recharge areas and emerges after intercepting Quaternary sediments at the edge of the basin. Spring water is weakly confined.

Group 4, HeiLT2 and HLT1. These 2 springs have limited discharge $(<51 / \mathrm{s})$ and water temperature is influenced by air temperature. They might be impacted by human activities with relative higher $\mathrm{Cl}^{-}$concentrations. The infiltration is controlled by fractures.

Group 5, HLT2. The spring discharge and hydrochemical parameters oscillate greatly during dry and wet seasons. Near the outlet of the spring, there is a karst window with open air along the groundwater flow path. This is a typical shallow karst spring.

\section{Conclusions}

The hydrochemical characteristic of the fault-controlled karst basin is highly complex as a consequence of intense tectonic activities. Within the fault-controlled Baiyi Basin, five groups of springs are identified. There are not only epikarst springs, shallow karst springs, and confined karst springs, but also a non-karst spring. In some cases, deep groundwater might be involved in the water cycle in the fault-controlled karst basin.

The water isotope data shows that QLT Springs (QLT1 to QLT4) and HeiLT1 share a common recharge water source.

Nitrate concentrations for 9 out of 10 springs during the study period exceeded the drinking water standard of $10 \mathrm{mg} / \mathrm{l}$.

\section{Acknowledgements}

We are grateful to two anonymous reviewers, Yongli Gao and the editor for their constructive suggestions and (or) improving writing. This research is supported by China NSFC grant41371040.

\section{References}

Wang Y, Li Y, Tan J, Zhang G, He R. 2003. Storage rule of karst water in fault basins. Yunnan Science and Technology Publishing House, Kunming.

Šebela S, Kogovšek J. 2006. Hydrochemical characteristics and tectonic situation and of selected springs in central and NW Yunnan province, China. Acta Carsologica 35 (1): 23-33.

Kunming EPA. 1988. A report on the multi-subject comprehensive investigation of the protection district of sources of water at Songhuaba Kunming City, unpublished.

Greenberg AE, Clesceri LS, Eaton AD, editors. 1992. Standard methods for the examination of water and waste water, 18th ed. American Public Health Association, Washington. 
